\title{
7 \\ DEVELOPMENT AND THE ENVIRONMENT: PERSPECTIVES ON DEGRADATION AND CONSERVATION ISSUES
}

\author{
Dr John B. O. Aregbeyen
}

\section{Introduction}

Concern about the environment became increasingly recognised after the 1988 dumping of imported industrial toxic wastes at Koko Port in Bendel State of Nigeria. Since then, prevailing views on the need for sound environmental management which, of course, has come to be seen as a pre-requisite for sustainable development has inevitably become evident.

As a result, the Federal Government of Nigeria quickly demonstrated its commitment to the protection and improvement of the environment through the promulgation of Decrees No. 58 of 1988 and No. 50 of 1989 establishing the Federal Environmental Protection Agency (FEPA) and the Natural Resources Conservation Council (NRCC) respectively, to carry out the effective management and control of the environment and to ensure that the exploitation of natural resources meets with stipulated guidelines which should, of course, be consistent with environmental protection objectives.

In view of the recent efforts by the various levels of the Nigerian government to stem environmental degradation in the country, it is our purpose here to draw attention not only to the importance of natural resources conservation as a key solution to environmental degradation in the country but also to its role in the developmental process. In doing this, the paper is divided into five parts. Part two discusses the importance of sound environmental management in the developmental process, especially in a developing country like ours. 
Part three examines the effects of environmental degradation on the Nigerian economy, while part four reflects on the need to accord high priority to natural resources conservation in Nigeria. The last part concludes the paper with policy recommendations.

\section{Developmental Concerns}

The Nigerian economy is without doubt heavily dependent on her natural resources base, especially in oil, natural gas, iron, agriculture, forestry, wildlife, water and fisheries. Moreover, a large proportion of the Nigerian populations make their living from land and water resources. Beyond that, it has become evident that the direction of our economic fortune must be determined internally and, to a greater extent, with the use of our own resources. This point to the need to effectively manage our natural resources especially when it is obvious that we can least afford the opportunity cost of the irreversible loss of our renewable natural resources or the inevitably expensive efforts to remedy environmental degradation.

However, it should be stated without reservation that poverty is, according to the World Bank, the worst form of pollution. Yet, any attempt to bring about improvement in the living standards of a population involves changes in the natural environment often in an adverse way (World Bank 1979: 3). The point is that to develop, it is imperative that we exploit certain desired available resources at our disposal. These, of course, include natural as well as human and material resources - precisely to enable us industrialize. Conversely, the contradiction arises from the fact that Nigeria wants a clean environment, while, at the same time, it is equally committed to economic growth, an improved quality of life and a rising standard of living. Invariably, exploitation of natural resources and industrialization are both potential sources of pollution.

Let the point be made here that conflicts among important goals such as these cannot be avoided; nevertheless, good environmental management requires the design of a pollution control programme capable of reducing substantially the cost of cleaning up the environment as well as ensuring sustainability of renewable resources.

Very pertinent, however, is the need to realize that the proper management of our resources does not refer only to the desire to conserve and effectively manage our renewable natural resources, control of air, water, land, and industrial pollution as well as the concern for the general well-being of the people alone, but more importantly, it also involves the democratization of the development process. This, necessarily, is with a view to creating a conducive environment for sustainable development which requires the mobilization of people, granting the poor access to basic factors of production, that creation of employment opportunities, improved equity in the distribution of 
income and the creation of a favourable investment climate as well as the establishment of an atmosphere of peace and stability (Adedeji 1990:1-2; Aregbeyen 1991:40-52).

Interestingly, there is mounting evidence to show that the net result of the above is a gradual arrest of the usual vicious cycle of increasing poverty which has hitherto been recognized to be responsible for further ecological degradation (Lee and Goodland 1986:36-39).

In the event that we fail to heed the warning to effectively manage our environment, what then are the consequences? To this and other related issues, we shall now turn our searchlight.

\section{The Effects of Environmental Degradation}

It is important to draw our attention to the fact that within the economic system, the natural environment performs three principal functions. It acts as a life-support system, it is a resource supplier, and more importantly, a waste assimilator. However, the natural environment has a limited capacity to which it can assimilate waste. When this capacity is exceeded, its quality begins to deteriorate and thus can no longer perform its normal traditional functions as a supplier of natural resources (which, of course, forms the very foundations of the material prosperity of this nation) as well as a life-support system (Aregbeyen 1989: 3-5). Consequently, the inability of the natural environment to perform the three major functions leads to environmental degradation.

Unfortunately, however, the economic activities of man has continued to generate serious environmental hazards which has greatly been exacerbated in Nigeria by her rapid population growth and the growing level of industrial activities. The resulting environmental degradation emanates mainly from air and water pollution, soil erosion, desertification, poor drainage and inadequate sewage and refuse disposal system.

However, the problems easily identified with land and water in Nigeria are of two categories - renewable and non-renewable resource degradation. Those of renewable resource degradation include: deforestation, fisheries and wildlife losses. Non- renewable resources degradation but maintainable resources include: soil losses, land and coastal erosion, desert encroachment, mining and quarrying. Apart from the danger this poor environmental condition poses to human health, desertification and soil erosion, in particular, are seriously destroying large areas of the nation's land by rendering the soil unproductive. For instance, desertification is increasingly becoming a very serious problem in many parts of the northern states such as So-koto, Katsina, Kano, and Borno. In the same vein, soil erosion has reached catastrophic proportions in Anambra and Imo States as well as the coastal areas of Akwa-Ibom, Bendel, Cross River, Lagos and Rivers States (FRN 1990:303). 


\section{2}

Besides, because of the composite relationship of the environment, there is often a chain of cause and effect where a worsening in one leads to a deterioration in the others, as if in a vicious circle. For example, forest losses - probably as a result of improper resource management such as bush burning, indiscriminate and non-sustainable logging etc lead to soil erosion and flooding disasters. The long-run effect is less rainfall in the absence of trees and, therefore, less available land for agriculture. Moreover, demand for valuable forest products such as industrial and fuel wood, building materials, timber for export, traditional hunting, poaching and non-wood product gathering (such as foods, spices, medicines, etc) become scarce and, therefore, much more expensive. Nigeria's forests which cover about 133,807 square kilometers (FRN 1990: 79), for instance, provide valuable economic products. Unfortunately, however, there already exists a deficit of three million cubicmetres of fuel wood and poles in both the northern and southern states of Nigeria respectively (FRN 1990: 79). On the other hand, the pollution of both surface and underground water creates the problem of clean and safe water supplies for urban populations, industrial use, irrigation and fisheries. Furthermore, it creates the problem of clearing water hyacinth which is very expensive.

It is, however, important to point out that, although, ecological disasters such as floods, soil erosion and drought could be exacerbated by the economic activities of man, nevertheless, they often result from natural phenomenon which, to a large extent, is more often beyond human control. When this happens, it often leads to:

(i) food shortages and possibly famine as well as increased loss to farmers due to crop failures;

(ii) increased food prices and increased food imports with the resultant adverse impact on already scarce foreign exchange and increasing balance of payments problems,

(iii) income loss to livestock owners (who may lose many of their livestock) due to lack of adequate grazing pasturage;

(iv) losses in foreign exchange earnings due to the destruction of export crops; and

(v) increased susceptibility to ill-health due to possible malnutrition resulting from poor diet, shortage of meat and fish, lack of nutrition and safe potable water, poor sanitation, etc.

It will be recalled that in 1981, the Federal Government established a fund for Ecological Disasters to assist communities affected by severe ecological disturbances. This is perhaps, a desirable step to- 
wards the right direction, nevertheless, it is not enough to provide funds for the management of crisis situations where it is apparent that preventing is better than curing. The important point is that government should strive to minimize and, where possible eliminate the occurrences of ecological disasters, the effect of which are known to exert untold hardship and economic instability on society particularly the affected communities. Obviously, flooding and erosion are, to a large extent, controlable, while irrigation, to an appreciable degree, minimizes the adverse effects of drought on agriculture and the availability of water for economic purposes.

Although, the Federal Government, through the Federal Ministry of Science and Technology, "accepts the challenge of providing, through research, the reliable data base and appropriate technologies for the solution of the problem of ecological disasters in the country (Emovon 1987: iii) however, available data till date on the impact (especially in monetary terms) of various environmental problems on the Nigerian economy are scanty and are in most cases of doubtful reliability. Nonetheless, some estimates have been made using the limited data available. It is estimated that the various environmental problems in Nigeria would have the following "order of magnitude" impacts on GDP: (World Bank 1990:1 of 3).

\begin{tabular}{l|l}
\hline Environmental problem & $\begin{array}{l}\text { Amount per annum in million } \\
\text { dollars }\end{array}$ \\
\hline 1. Water hyacinth & 50.00 \\
2. Water contamination & $1,000.00$ \\
3. Deforestation & 750.00 \\
4. Fishery losses & 10.00 \\
5. Wildlife losses & 10.00 \\
6. Soil degradation & $3,000.00$ \\
7. Gully erosion & 20.00 \\
8. Coastal erosion & 30.00 \\
\hline Total & $\$ 4.9$ billion per year \\
\hline
\end{tabular}

Average Exchange Rate for 1990 was about N9.00 = $\$ 1.00$ 
Unfortunately, the Nigerian economy is still heavily dependent on land and water resources, especially with respect to agriculture, forestry and fisheries - either for domestic consumption or for exports. The implication is that where resources are adversely affected by damage to the environment, the result is likely to lead to deterioration in human health and quality of life as a result of contaminated water, loss of valuable foreign exchange, insufficient and poor food derivable from the forest products and economic backwardness. The basis for this prediction lies in the increasing belief that a person's health determines, to a large extent, his ability to contribute to the accelerated growth and well-being of society. But if it is true as it is generally believed, that the potential manpower needs of any nation is dependent on the health of its citizens, it therefore means that any nation that fails to care for its environmental problems is most likely to be poor, underdeveloped and much more likely to be without peace and stability.

\section{The Need for Conservation}

Conservation, which means saving or the careful management of natural resources involves the exploitation of valuable natural resources in such a way that would serve us better and longer than they would otherwise. In other words, we do not conserve a resource by leaving it idle but by making the best economic use of it (Parson, 1964).

Nigeria, like any other country, has her natural resources which make up the wealth of the nation. These natural resources include among others oil, iron, natural gas, tin, forests, soil, rivers and streams, fisheries, wildlife, livestock and the aesthetic beauty of our numerous natural land formations. Apparently, important natural resources such as these which to a large extent play a significant role in the nation's socio- economic welfare require careful management.

Although, preservation does not mean conservation, nevertheless, it is important to preserve natural treasures which might face the danger of extinction. These include rare animals or endangered wildlife species, aesthetic resources and ecological wonders such as warm springs, falls and hills as prized antiques.

The contribution of our natural- resources to the nation's economic and social welfare cannot be overemphasized. For example, petroleum provides about $90 \%$ of Nigeria's export earnings which accounts for about $21 \%$ of the GDP. Moreover, this resource places the country in an influential position with the countries to which it sells. Other minerals, such as iron and natural gas, are not only potential sources of revenue especially when the projects under construction are fully completed but also a spring 
Development and the Environment 105

board to Nigeria's industrialization, technological development and self-reliance.

Also, the Nigerian savannah is home for different species of wildlife as well as grazing land for cattle which, of course, is the main source of meat for most Nigerians.

The network of rivers and streams as well as a beautiful coast line are sources of energy (hydro-electric power), clean water supply suitable for consumption, irrigation, fisheries, industrial usage, recreation, transportation etc.

We can see from the above exposition how vital these natural resources are to the economy. And, if for any reason, the nation allows these resources to be wasted, the economy will become weak to the extent that the country will be unable to support her teeming present and future populations.

\section{Conclusion and Recommendations}

The Nigerian environment has been under constant threat from man's economic activities of production and consumption as well as from the harshness of natural phenomenon such as drought. It is, however; gratifying to note that much attention has recently been given to environmental and conservation matters through the establishment of agencies entrusted with the task of policing our environment.

In the light of the above, the following recommendations are proffered to ensure that government efforts to prevent environmental degradation is sustained:

1. There is a need for an intensive awareness campaign through the use of both the electronic and print media as well as through formal and informal education to stimulate public interest in environmental and conservation matters.

2. That appropriate and articulated environmental and conservation policies, regulations and incentives are put in place to help induce rational public behaviour towards the environment.

3. Existing environmental and conservation control, laws and regulations should be strengthened and, where necessary, appropriate new ones enacted, while the legal and institutional mechanism for their enforcement are also provided. 


\section{Annals of the Social Council of Nigeria}

4. Since keeping the environment clean is an important component of preventive health care, there is therefore, an urgent need for a properly planned health education scheme to enable the public to appreciate the need to prevent rather than cure diseases.

5. Realizing that available data on the Nigerian environment and especially on conservation of natural resources are scanty and most often of doubtful reliability, Research Institutes and the Universities should be encouraged to conduct research on relevant priotized areas by making money available for research. 


\section{References}

Adedeji, Adebayo (1990): "Adedeji's Seven Point Solution to Africa's Economic problems". The Guardian, Nigeria.

Aregbeyen, John B. O. (1991): Economic Implications of Preventive Health Care: The Case of Environmental Sanitation in Ibadan. Ibadan: Nigerian Institute of Social and Economic Research, NISER, (Monograph Series No. 2).

Aregbeyen, John B. O. (1989): "Economics of Environmental Management for Sustainable Development in Nigeria", Paper presented at a Workshop on Environment and Sustainable Development in Nigeria organised by UNDP and FEPA at Nicon Noga Hilton Hotel, Abuja (25-26 April, 1989).

Emovon, E. U. (1987): "Foreword" in V. O. Sagua et. al (eds) Ecological Disasters in Nigeria: Drought and Desertification (Proceedings of the National Workshop on Ecological Disasters in Nigeria: Drought and Desertification, Kano, 9-12, December 1985).

FRN Federal Republic of Nigeria (1990): First National Rolling Plan 1990-92 Lagos: Federal Ministry of Budget and Planning (Volume 1).

Lee, James and Robert Goodland (1986) : "Economic Development and the Environment" Finance and Development, Vol. 23, No. 4, (December).

Parson, Ruben L. (1964): Conserving American Resources. Englewood Cliffs, N. J.: Prentice-Hall fcic, (2nd Edition).

World Bank (1979): Environment and Development Washington: World Bank.

World Bank (1990): Nigeria: Environmental Assessment Report Draft Working Paper, Western Africa Department. 